\title{
ACRL Board actions, January 1992
}

\section{Highlights of the Midwinter Meetings of the ACRL Board of}

\section{Directors}

1

he Board of Directors of the Association of

College and Research Libraries met twice during the Midwinter Meeting in San Antonio: on January 26 and January 28,1992 . Highlights of their meetings are as follows:

President's 1992 Recruitment Theme. President Anne Beaubien announced the completion of the minority recruitment grant proposal. Mary George, grant proposal developer, met with ALA Executive Board subcommittees to review the proposal. The proposal would bring minority students between their junior and senior years to a campus where there is a library school and expose them to library science in hopes that they will choose it as a career.

The Strong Vocational Interest Inventory Task Force has finalized the demographic questions that will be asked along with the Strong Vocational Interest Inventory survey. A sample

\section{ACRL Board to hold planning retreat}

During their Midwinter Meetings, the ACRL Board of Directors voted to hold a full-day planning retreat. The Board will be reviewing and developing strategies for a 1993-95 strategic plan and will consider the process through which priorities within the association are set. The retreat will be held in Salt Lake City, Utah, on Saturday, April 11, 1992, from 9:00-5:00 p.m. just prior to the opening of ACRL's Sixth National Conference. ACRL's Executive Committee will hold its annual spring meeting Friday, April 10, from 9:00-5:00 p.m. population will receive survey instruments around mid-February 1992. After the return of the Strong Vocational Interest Surveys, the sample population will receive a Myers-Briggs instrument to complete and return. The results from these surveys will be reported at Annual Conference in San Francisco.

ALA Minority Fellow, Sheila Delacroix reported on her progress with DISCOVER and SIGI Plus. Librarian Profile questionnaires have gone out to 25 librarians. She will develop a single response from all of the information received from respondents and submit it to the Educational Testing Service (ETS). Changes in the profile will be discussed at a program during Annual Conference in San Francisco.

ALA Code of Professional Ethics. The Board endorsed a statement prepared by Board member Karin Begg asking that the code be revised and that it provide inspiration towards ideals, be broadenough for all situations, and be clear and simple.

Preconferences. The Board approved requests for two preconferences to be held before the 1993 ALA Annual Conference in New Orleans: 1) The Rare Books and Manuscripts Section will offer a preconference on June 22-25, 1993, tentatively titled "Special Collections in the 21st Century: How Others See Us and How We See Ourselves"; 2) The Science and Technology Section will offer a preconference on June 25, 1993, entitled "Science Reference Service: An Introduction for the General Reference Librarian."

WESS London Conference. The Western European Specialists Section (WESS) received Board approval to continue with planning for their 1994 London 


\section{New, Important \& Practical Books \\ From The Haworth Press, Inc.}

MAKING SENSE OF JOURNALS IN THE PHYSICAL SCIENCES

From Specialty Origins to Contemporary Assortment

Tony Stankus, MIS

Science Librarian, College of the Holy Cross

"Clear, practical, and unique.... we see that the purpose of making purchasing decisions is to help the library patron."

Virgil Diodato, MS, PhD, Associate Professor, School of Library and Information Science, University of Wisconsin at Milwaukee

The first step to saving money in the management of expensive science journals is knowing whether the specialty journals that you currently stock actually match the specialties pursued at your institution. This book introduces the fields and journals in such a way as to enable the librarian to negotiate journal holdings for appropriateness and relative value.

(Monographic Supplement 7 to The Serials Librarian.) $\$ 29.95$ hard. ISBN: 1-56024-180-2. Available Summer 1992.

\section{MAKING SENSE OF JOURNAIS \\ IN THE LIFE SCIENCES}

\section{From Specialty Origins to}

Contemporary Assortment

\section{Tony Stankus, MIS}

\section{"A must for those librarians concerned about} their biomedical serials collections. . . A wealth of information on the roles that each prominent journal plays today."

Frank R. Kellerman, MSLS, Biomedical Reference Librarian, Brown University

Serials and science librarians will benefit greatly from this helpful book.

(Monographic Supplement 8 to The Serials Librarian.) $\$ 39.95$ hard. ISBN: 1-56024-181-0. Available Summer 1992.

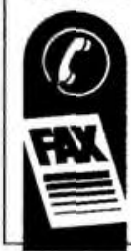

CALL OUR TOLL-FREE NUMBER: 1 - 800-3 - H A W OR T H 1-800-342-9678/US orders only/ 9am-5pm EST

FAX YOUR ORDER TO US: $607-722-1424$

\section{BUYERS AND BORRROWERS}

The Application of Consumer Theory to the Study of Library Use

Charles D. Emery, MPhil, ALA Associate Librarian, University of Waterloo, Ontario

Here is a practical new book that shows you and your students how to approach some long-standing and significant problems librarians need to address, such as Is the library reaching its target audience? What do shifts in use patterns reflect? How often can users be expected to visit the library? Can users be identified by category by the way they use the library? The book provides a sophisticated method of analyzing library use patterns by applying consumer-purchasing trendsyielding helpful and insightful information

\$24.95 hard ISBN: 1-56024-183-7.

Available Spring 1992.

\section{SCIENTIFIC JOURNALS}

\section{Improving Library Collections Through Analysis of Publishing Trends}

\section{Tony Stankus, MLS}

"A wonderfully written scholarly work on a topic of keen interest ... Must reading for all professionals."

James M. Matarazzo, PhD, Simmons College, Graduate School of Library \& Information Science

(Monographic Supplement 6 to The Serials Librarian.) \$29.95 hard. ISBN: 0-86656-905-7. 1990.

\section{SCIENTIFIC JOURNALS}

Issues in Library Selection and Management

Tony Stankus, MLS

"Tony Stankus has firmly established himself as one of the most productive investigators of the use of scientific journals. . . More works of this type are needed."

American Reference Books Annual

(Monographic Supplement to The Serials Librarian.) \$29.95 hard. ISBN: 0-86656-616-3. 1988.

Please note that these monographic supplements are not part of your regular subscription to The Serials Librarian.

The Haworth Press, Inc.

10AliceStreet, Binghamton, New York 13904-1580 
conference to be held between March and May. The conference is expected to attract 300 attendees.

Coalition for Networked Information. The Board heard a report from Thomas Kirk and Noreen Alldredge, representatives to the Task Force of the Coalition for Networked Information. Kirk and Alldredge see their role as that of bringing as much information as possible to the ACRL membership as well as helping the Coalition meet its objectives.

Joint Committee on the Definition of Membership Services. The Board approved the report from the Subcommittee, made up of both members of the Membership Committee and the Budget and Finance Committee. The report presented proposals which identified three categories for ACRL services and programs: a) basic membership services fully covered by membership dues, b) services and programs on a cost-recovery basis, and c) programs designed to produce net revenue.

ACRL Board Retreat. The Board agreed that the ACRL Strategic Plan, which was developed in 1986, should be reviewed. The Board will meet in Salt Lake City, April 11, in a planning retreat to review and develop strategies for a 1993-1995 strategic plan.

Constitution and Bylaws. The Board voted to change the makeup of the ACRL Board of Directors to include the Chair of the Planning Committee as an ex-officio member of the Board. The member- ship will vote on this constitutional change to the bylaws in the spring election.

WHCLIS. The Board endorsed the resolution put forth by the ACRL White House Conference Task Force and the Governmental Relations Committee that ACRL adopt the three top priority action issues of the conference as priority action areas for ALA. The three priority issues are: Omnibus Children and Youth Literacy; NREN available in all libraries and other information repositories at all levels; a national, regional, state, and local commitment of financial resources for library services.

Planning Committee. The Board accepted reviews of four committees: Audiovisual, Constitution and Bylaws, Budget and Finance, and Academic Status, and approved the continuance of the work of these committees.

Taxation on Periodical Subscriptions. The Board endorsed the resolution from ALCTS against taxation of periodicals subscriptions.

Improvement of Information Act. The Board endorsed the resolution from GODORT.

Sixth National Conference-Salt I ake City. Executive Committee Chair Joseph Boissé reported that things are going well. Exhibitors are past $100 \%$ of the projected numbers and budget. An outstanding program has been arranged and we are now looking forward to a very large conference registration.

\section{A career in BI: Dead end or stepping stone?}

Choosing a career in bibliographic instruction (BI) was the topic for discussion at the January 26 , Midwinter discussion forum sponsored by the Bibliographic Instruction Section's Continuing Education Committee. Discussion starter Evan Farber, Earlham College, remarked that many of the qualities that make a good BI librarian are also qualities that make a successful library administrator. BI librarians must be in touch with issues in higher education and all aspects of the library and have political skills. He recounted the number of recent ACRL presidents that have come from the ranks of bibliographic instruction.

Karen Williams, University of Arizona, Pointed out that a successful career does not necessarily mean moving up the career ladder, and viewed BI as a useful stepping stone to a number of different career paths. Williams said that BI librarianship could be a dead end unless it is combined with other duties, such as working at the reference desk, in order to remain in touch with issues and operations in other areas of the library.

Bill Miller, Florida Atlantic University, stated that there were fewer chances for supervisory experience working in the public services and this could be a hindrance to job advancement. $\mathrm{He}$ also remarked that bibliographic instruction librarians have the closest ties to faculty in their roles as teachers.

Members of the audience agreed and felt that their interactions and common interests with the faculty had enhanced their standing with the university community. Comments from the audience indicated that many enjoyed their work in $\mathrm{BI}$ and did not see it as hindrance or a dead-end job. The hour ended with a discussion about why BI is not part of the curriculum at many library schools, or is taught by practitioners instead of library school faculty.--Jill Newby, Engineering Librarian, Yale University 